\title{
Морфофункціональне обгрунтування тазової тонкокишкової резервуарної конструкціі нового типу
}

В. М. Мельник, О. І. Пойда, А. А. Кадір

Національний медичний університет імені О. О. Богомольця, м. Київ

\section{Morphofunctional substantiation of the pelvic small-intestinal reservoir construction of a new type}

\author{
V. M. Melnyk, O. I. Poyda, A. A. Qadir
}

Bogomolets National Medical University, Kyiv

Забезпечення сприятливих функціональних результатів і належної якості життя пацієнтів після виконання колектомії з наднизькою передньою резекцією прямої кишки, мукозектомією хірургічного анального каналу можливе лише у разі формування тазової тонкокишкової резервуарної конструкції. Відомо, що функціональні результати значною мірою залежать від типу сформованої конструкції і особливостей морфофункціональної перебудови тонкої кишки.

Мета дослідження: визначити фактори впливу на функціональні результати після формування тазової тонкокишкової резервуарної конструкції нового типу.

Змістом поняття тазової тонкокишкової резервуарної конструкції нового типу вважаємо анатомічні взаємовідношення, які виникають між петлями термінального відділу тонкої кишки, термінальним відділом тонкої кишки та демукозованим хірургічним анальним каналом після формування тонкокишкового резервуара та ілеоендоанального анастомоза.

Ми розробили тазову тонкокишкову резервуарну конструкцію нового типу, використавши авторські способи формування тонкокишкового резервуара та ілеоендоанального анастомоза та вважаючи важливими заходи, спрямовані на забезпечення неускладненого перебігу репаративних процесів ділянки ілеоендоанального анастомоза та тонкокишкового резервуара; фізіологічної затримки просування вмісту і перебігу процесів кишкового травлення та всмоктування; відновлення функції анального тримання.

Розроблену тазову тонкокишкову резервуарну конструкцію нового типу використано у 32 пацієнтів після колектомії, наднизької передньої резекції прямої кишки, мукозектомії хірургічного анального каналу, оперованих 3 приводу тяжких непухлинних захворювань товстої кишки: виразкового коліту - 14 (43,8\%), хвороби Крона товстої кишки з ії тотальним ураженням - 8 (25,0\%), родинного аденоматозного поліпозу - 10 (31,2\%). Чоловіків було 18 (56,2\%), жінок - 14 (43,8\%). Вік пацієнтів становив 18 - 35 років. Первинні реконструктивно-відновні операції виконані 25 (78,1\%) пацієнтам, вторинні - 7 (21,9\%).
Внутрішньочеревні післяопераційні ускладнення виникли у 2 (6,2\%) пацієнтів: тонкокишково-піхвова нориця - у 1, абсцес порожнини малого таза - у 1. Після операції жоден пацієнт не помер.

Функціональні результати оцінювали через 3 роки - в період завершення адаптаційних процесів до сформованої конструкції. Частота випорожнень кашоподібним хімусом у переважної більшості пацієнтів становила 3 - 5 разів протягом доби. У 2 (6,2\%) пацієнтів періодично спостерігали анальну інконтиненцію, у кожного з них - після вторинних реконструктивно-відновних операцій. У всіх оперованих пацієнтів встановлено постколектомічний синдром І ступеня.

Факторами забезпечення сприятливих функціональних результатів вважаємо анатомічні особливості розробленої тазової тонкокишкової резервуарної конструкції, а також особливості депонування вмісту в усіх анатомічних відділах тонкої кишки. Ці фактори обумовлюють характерні морфофункціональні зміни тонкої кишки. На підставі рентгенологічного контролю транзиту барієвої суміші виявлені певні закономірності розташування тонкої кишки в черевній порожнині. Порожня кишка розміщувалась в проекції навколопупкової ділянки, клубова в проекції видалених висхідної, поперечної, низхідної та сигмоподібної ободових кишок. Ділянка тазового тонкокишкового резервуара значною мірою була аналогом верхнього, середнього та нижнього ампулярних відділів прямої кишки. Колонізація тонкої кишки також мала свої особливості та різний ступінь вираженості в проксимально-дистальному напрямку. Зміни петель порожньої кишки були мінімальними та мали вигляд перістого або поперечного малюнка слизової оболонки без явних структурних змін м'язової оболонки. Зміни в ділянках клубової кишки були більш значними, спостерігали звуження просвіту, а ділянки між цими звуженнями були аналогічні сегментам ободової кишки. В проекції сформованого тонкокишкового резервуара ділянки між звуженнями набували округлої форми, діаметр їх був більшим, ніж діаметр кишки, розташованої проксимально. Він мав вигляд ампули прямої кишки. 
Таким чином, особливості депонування вмісту в збережених відділах тонкої кишки після формування тазової тонкокишкової резервуарної конструкції нового типу обумовлюють особливості ії морфофункціональної трансформації на зразок кишкового каналу здорової людини, що сприяє забезпеченню задовільних функціональних результатів.

\section{Висновки}

1. Факторами впливу на функціональні результати після формування тазової тонкокишкової резервуарної конструкції є тип сформованої конструкції, особливості морфофункціональної трансформації тонкої кишки, перебігу процесів кишкового травлення та всмоктування.

2. Використання розробленої тазової тонкокишкової резервуарної конструкції нового типу сприяло значному покращенню функціональних результатів у пацієнтів після колектомії, наднизької передньої резекції прямої кишки, мукозектомії. 